\title{
Toxicity of isolated phenolic compounds from Acorus calamus L. to control Spodoptera litura (Lepidoptera: Noctuidae) under laboratory conditions
}

Phatcharaphon Wiwattanawanichakun ${ }^{1}$, Siriwan Saehlee ${ }^{1}$, Thitaree Yooboon ${ }^{1}$, Nutchaya Kumrungsee ${ }^{2}$, Saksit Nobsathian ${ }^{3^{*}}$ and Vasakorn Bullangpoti ${ }^{1^{*}}$ (D)

\begin{abstract}
Background: Spodoptera litura (Lepidoptera: Noctuidae), the tobacco cutworm, is an prominent agricultural pest. To reduce the use of chemical pesticides that cause health problems and that leave residue in the environment, some botanical pesticides have been developed. Our research aimed to evaluate the insecticidal efficacy of Acorus calamus $L$. extract for the control of $S$. litura under laboratory conditions.

Results: After $24 \mathrm{~h}$ of topical application, the A. calamus methanolic crude extract showed toxicity against secondary instar S. litura larvae ( $\left.\mathrm{LD}_{50} \sim 7.438 \mu \mathrm{g} / \mathrm{larva}\right)$. Chrysin (5,7-dihydroxy flavone), one of the isolated phenolic compounds, showed optimal control efficiency $\left(\mathrm{LD}_{50} \sim 2.752 \mathrm{\mu g} / \mathrm{larva}\right)$ and showed a reduction in carboxylesterase activities, which have detoxification reduction roles in larvae.

Conclusion: Chrysin in the crude extract of A. calamus may be an active compound to control this pest, and it may be applied as an alternative to minimize the usage of chemical insecticides.
\end{abstract}

Keywords: Spodoptera litura, Noctuidae, Acorus calamus, Chrysin

\footnotetext{
*Correspondence: saksit.nob@mahidol.ac.th; fscivkb@ku.ac.th

1 Animal Toxicology and Physiology Speciality Research Unit, Department

of Zoology, Faculty of Science, Kasetsart University, Phahonyothin Road,

Bangkok 10900, Thailand

${ }^{3}$ Nakhonsawan Campus, Mahidol University, 402/1 Moo 5 Khaothong,

Phrayuhakiri District, Nakhonsawan 60130, Thailand

Full list of author information is available at the end of the article
} regulation or exceeds the permitted use, you will need to obtain permission directly from the copyright holder. To view a copy of this licence, visit http://creativecommons.org/licenses/by/4.0/. The Creative Commons Public Domain Dedication waiver (http://creativeco mmons.org/publicdomain/zero/1.0/) applies to the data made available in this article, unless otherwise stated in a credit line to the data. 


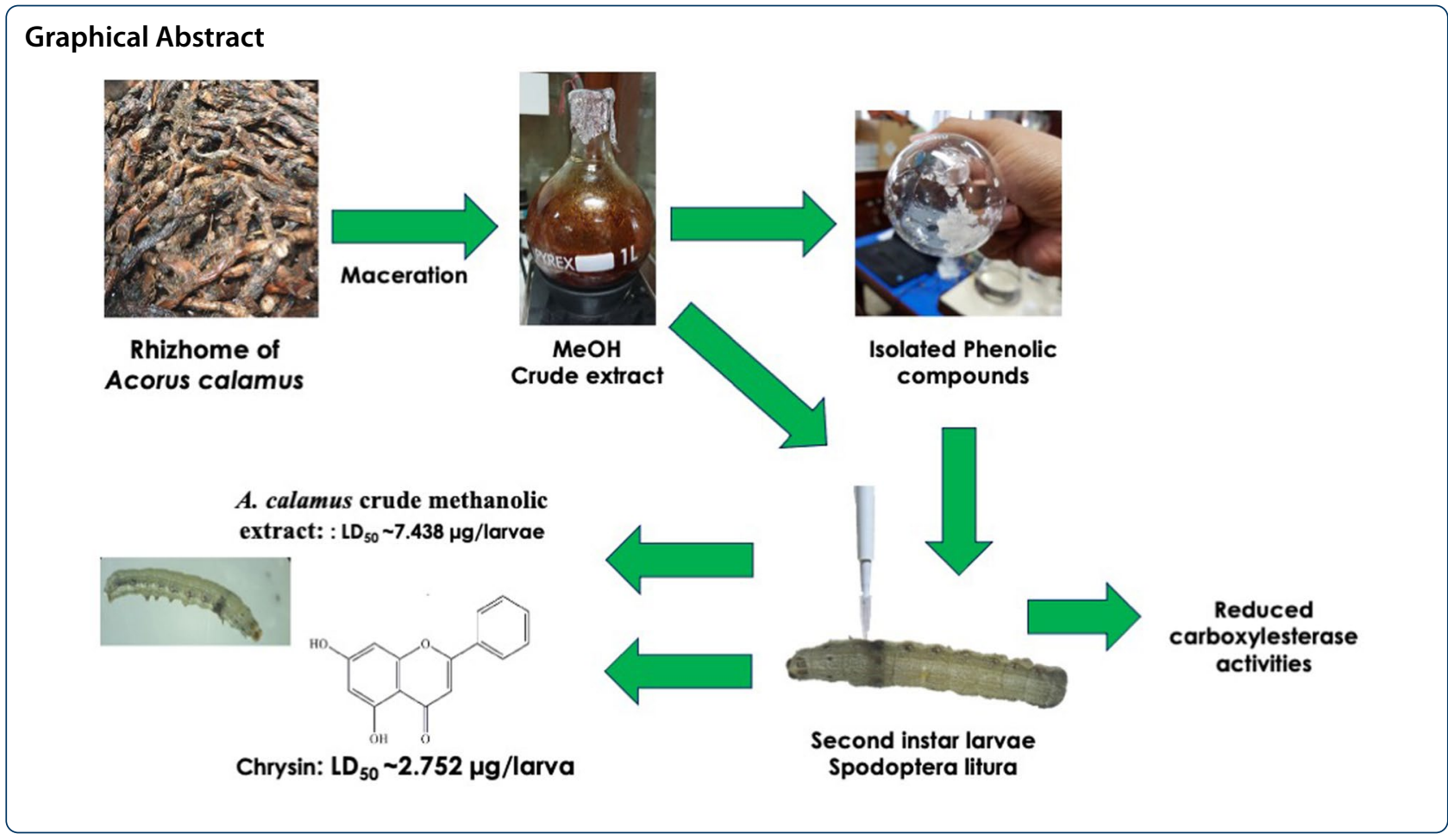

\section{Background}

Noctuidae, which contains some of the most prominent insect pests in agriculture, is the largest family in the order Lepidoptera. Our research interest lies in the tobacco cutworm [Spodoptera litura (Lepidoptera: Noctuidae)], which is an important crop pest in regions worldwide [1]. This species feeds on many varieties of plants, such as corn, rice, peanuts, sorghum, Bermuda grass, and cotton $[2,3]$. This species parasitizes the plants through vigorous larval eating patterns, often leaving the leaves destroyed. Additionally, moths are responsible for decreasing yield in agricultural crops [4]. Currently, the management of this pest mainly relies on synthetic chemicals, including organophosphates, carbamates, and pyrethroids. However, S. litura has developed substantial resistance to various classes of chemicals following the long-term utilization of synthetic pesticides [5-7]. Several farmers use high doses of synthetic insecticides. But inappropriate use of synthetic insecticides can result in greater environmental problems and the loss of on-farm biodiversity, as well as damage to human health [8].

Botanical insecticides have been used to control many pests over the last two decades, as they show minimal toxicity to mammals. Several isolated compounds from plant extracts or essential oils have been evaluated for their insecticidal activity [9]. For example, neem has had a substantial global impact as a botanical insecticide [10-13]. There are many publications that show that plant extracts such as neem, rotenone, toosendanin [14], Itoa orientalis Hemsl [12], piperine, $\beta$-asarone [15] and Alpinia galanga [16] efficiently control S. litura.

This research aimed to evaluate the efficiency of Acorus calamus L. for controlling S. litura. Humans use the extract of Acorus calamus L. to prevent stress and memory deficits, because it inhibits inflammation and controls oxidative stress [17]. In addition, A. calamus is a botanical extract for pest management and a supplement in primary health care worldwide [18]. Numerous documents have recorded that $A$. calamus has toxic effects against many insects $[19,20]$. Its essential rhizome oil showed a sterilizing effect against the eggs of Sitophilus granaries L., Sitophilus oryzae L., and Callosobruchus chinensis L. [21], and it showed larvicidal activity against Culex quinquefasciatus L. [19]. This plant originated in Asia, but has been cultivated in South Africa since early colonial times for use in treating indigestion, flatulence and diarrhoea. It is distributed throughout the countryside and has become naturalized [22]. The compound $\beta$-asarone, isolated from the $A$. calamus rhizome, is a potent growth inhibitor and antifeedant to the variegated cutworm Peridroma saucia L. [20].

In this research, we also investigated phenolic compounds isolated from A. calamus. Many studies have described that $A$. calamus has various phenolic compounds [23-25]. Phenolic compounds were recorded as toxic to some insects, such as red imported fire ants 
(Solenopsis invicta) [26], termites [27], and fall armyworms [28].

It has proven especially difficult to characterize phenonic activity in insect herbivores. Appel and Schultz (1992) [29] described that variation among insect species in midgut conditions, mainly redox potential, and $\mathrm{pH}$, yields variable impacts of phenolics on insects. Redox conditions and $\mathrm{pH}$ are influenced by intrinsic physiological characteristics of the insect and by foliar oxidative enzymes, nonenzymatic oxidants, and reductants. All may affect detoxification enzymes and may be related to toxicity by pesticides. In many cases, oxidative activation may be necessary before biological impacts can be observed.

In this study, we produced an effective crude extract from the $A$. calamus rhizome with a methanolic solvent and isolated the phenolic compounds to control S. litura. There is little research on the efficacy of phenolics isolated from A. calamus on S. litura. The aim of this work was to determine the toxic effects of $A$. calamus on $S$. litura and of the detoxification enzyme activities to estimate insect resistance.

\section{Materials and methods Insect rearing}

S. litura larvae were obtained from the Animal Toxicology and Physiology Research Unit Laboratory of Kasetsart University, Bangkok, Thailand. S. litura larvae were raised in $23 \times 13 \times 7 \mathrm{~cm}^{3}$ plastic boxes during the first- to third-instar larval stage and in $26 \times 40 \times 20 \mathrm{~cm}^{3}$ plastic boxes for the fourth-instar larval stage. The temperature was set to $25 \pm 2{ }^{\circ} \mathrm{C}$ with $75 \%$ relative humidity and a photoperiod of 16:8 (L:D). S. litura larvae were fed an artificial diet (a mixture of $240 \mathrm{~g}$ green bean, $25 \mathrm{~g}$ agar, $40 \mathrm{ml}$ mixed vitamin solution, $5 \mathrm{~g}$ ascorbic acid, $40 \mathrm{ml}$ amoxil solution, $3 \mathrm{~g}$ sorbic acid, $5 \mathrm{~g}$ methylparaben, $20 \mathrm{~g}$ yeast, $4 \mathrm{ml}$ of $40 \%$ formalin and $1.41 \mathrm{~L}$ water). The artificial diet ingredients were the same as those described by Yooboon et al. [30]. To allow oviposition, the moths were moved to cages with filter papers and $10 \% \mathrm{v} / \mathrm{v}$ sugar solution in water after emergence. The second instars were used in topical application assays as described below. All experimental procedures were performed with approval of the Animal Ethics Committee of Kasetsart University.

\section{Plant material}

A. calamus was collected from Chiangmai Province, Thailand, and was registered at the Princess Sirindhorn Plant Herbarium of the Plant Varieties Protection Division, Department of Agriculture, Thailand, with voucher No. BKF 071393. Rhizomes were cleaned and dried at room temperature, powdered with a grinding machine (WF-10) and stored in Zip-lock bags.

\section{Extraction method}

The rhizomes of $A$. calamus were extracted with methanol $(\mathrm{MeOH})$ to produce toxic crude methanol, and its bioactive compounds were isolated with the modified method of Nobsathian et al. [31].

\section{Identification}

The air-dried and finely ground powder of the A. calamus L. rhizome was extracted with methanol. The crude extract was filtered and dried using a rotary evaporator (IKA ${ }^{\circledR} \mathrm{RV} 10$ basic, Thailand) and stored at $4{ }^{\circ} \mathrm{C}$ until further use in the experiments. The isolated compound was obtained by using chromatography techniques.

The dried and finely ground powdered rhizome $(1.70 \mathrm{~kg})$ of $A$. calamus was soaked with $\mathrm{MeOH}$ at room temperature to produce a crude $\mathrm{MeOH}$ extract $(215.00 \mathrm{~g})$. After dissolution in MeOH:EtOAc (1:1) and solvent removal, a soluble fraction $(105.000 \mathrm{~g})$ of crude $\mathrm{MeOH}$ :EtOAc (1:1) was obtained. After removing solvents, the obtained active MeOH:EtOAc (1:1) fraction $(816.0 \mathrm{~g})$ was divided into three portions. Each portion (116.6 g) was subjected to VLC over Si-gel (200 g) on a sintered glass funnel (i.d. $13.0 \mathrm{~cm} \times 4.3 \mathrm{~cm}$ ) and eluted with EtOAc-hexanes and $\mathrm{MeOH}-\mathrm{EtOAc}$ gradients. Fractions $(1000 \mathrm{~mL}$ each) were collected and combined based on their thin layer chromatography behaviours to produce fractions. $\mathrm{A}_{1}-\mathrm{A}_{6}$. Fraction $\mathrm{A}_{3}(2.57 \mathrm{~g})$ provided 4-hydroxyacetophenone (4) (125.20 mg) after two consecutive Si-gel CCs ( $\mathrm{CH} 2 \mathrm{Cl} 2-$ hexane gradients), followed by recrystallization from $\mathrm{MeOH}-\mathrm{CH}_{2} \mathrm{Cl}_{2}$. Fraction $\mathrm{A}_{3}(13.20 \mathrm{~g})$ produced fractions $\mathrm{B}_{1}-\mathrm{B}_{4}$ after Si-gel CC (ethyl acetate-hexanes and $\mathrm{MeOH}$-ethyl acetate gradients). Fraction B3 $(5.20 \mathrm{~g})$ produced fractions $\mathrm{C}_{1}-\mathrm{C}_{6}$ after Si-gel $\mathrm{CC}$ (acetone-hexanes and $\mathrm{MeOH}$-acetone gradients). Fraction C1 (1.52 g) produced pachypophyllin (1) (121.2 $\mathrm{mg}$ ) as a white needle after recrystallization from $\mathrm{MeOH}$-ethyl acetate. Fraction $\mathrm{B}_{3}(780.1 \mathrm{mg})$ provided galangin (2) (101.1 mg) after recrystallization from $\mathrm{MeOH}-\mathrm{CH} 2 \mathrm{Cl} 2$. The residue of fraction $\mathrm{B} 3(211.4 \mathrm{mg})$ yielded chrysin (3) $(21.20 \mathrm{mg})$ after recrystallization from $\mathrm{CH} 2 \mathrm{Cl} 2-$ hexanes.

All pure compounds were verified by their physical properties and spectroscopic data, as found in the literature [32-35].

\section{Toxicity assay}

The toxicities of the crude extract and isolated compounds were determined following the method of Yooboon et al. [9]. The extract and compounds were individually applied directly to the thoracic region of the second instars (42.31 mg/larva), as this stage of larvae were widespread on other plants, with a microapplicator at a 
dose of 0-30 $\mu \mathrm{g} /$ larva, using acetone as a control because it was used as the dissolving solvent (five replicates, five treatments, $n=150$ per dose). After application, each larva was placed in a Petri dish with filter paper and then moved to a new sealed plastic tray $(30 \times 20 \times 10$ $\mathrm{cm}^{3}$ ), provided with an artificial diet, covered with a black cover, and placed under controlled conditions in a rearing room with moistened filter paper. Mortality was counted after $24 \mathrm{~h}$ of exposure. The median lethal dose was calculated by probit analysis (StatPlus Program for Mac 2017, AnalystSoft, Walnut, CA, USA).

\section{Detoxification enzyme assays}

This research determined some of the major detoxification enzymes in insects, carboxylesterase (CE) and glutathione-S-transferase (GST) activity, using a microplate reader technique. Second instars of S. litura were treated with A. calamus crude extract and its isolated compounds at the median lethal dose $\left(\mathrm{LD}_{50}\right)$ that was determined from the topical application.

Five replicates of the surviving larvae $24 \mathrm{~h}$ after treatment were homogenized in $1 \%$ Triton-X-100 and $0.5 \mathrm{~mL}$ of $100 \mathrm{mM}$ potassium phosphate buffer, $\mathrm{pH}$ 7.2. After centrifugation at $12,000 \mathrm{rpm}$ for $15 \mathrm{~min}$ at $4{ }^{\circ} \mathrm{C}$, the supernatant was used as an enzyme source.

$\mathrm{CE}$ activity was determined with a microplate reader by a modified method from Bullangpoti et al. [36], which uses $p$-nitrophenyl acetate (pNPA) as the substrate. Enzyme activity was measured in kinetic mode at $410 \mathrm{~nm}$ and $37{ }^{\circ} \mathrm{C}$ for $90 \mathrm{~s}$. The activity was determined by the extinction coefficient of 176.4705 for pNPA.

To determine GST activity with a microplate reader, the method of Oppenoorth et al. [37], which used $150 \mathrm{mM}$ 1-chloro-2,4-dinitrobenzene (CDNB) as the substrate, was modified. The optical density was recorded in kinetic mode at $340 \mathrm{~nm}$ and $37^{\circ} \mathrm{C}$ for $30 \mathrm{~s}$. The extinction coefficient of GST activity was 0.0096 .

The protein content of each fraction that was used as an enzyme source was determined by the method of Bradford (1976) [38] using a Bradford kit (Bio-Rad Laboratories, Hercules, CA, USA) before measuring enzyme activities. Three biological replicates per enzyme fraction were estimated.

All statistical analyses were performed in the StatPlus Program (StatPlus Program for Mac 2017, AnalystSoft, Walnut, CA, USA).

\section{Results}

\section{Crude and isolation compound}

The percent yields of crude methanol, the 1:1 $\mathrm{MeOH}: \mathrm{EtOAc}$ soluble fraction and all pure compounds are shown in Tables 1 and 2.
Table 1 \%yield of crude methanol, 1:1 MeOH:EtOAc soluble fraction

\begin{tabular}{lcll}
\hline Sample & Dry weight $(\mathbf{g})$ & Crude extract $(\mathbf{g})$ & \% Yield \\
\hline Powder of rhizome & 1700.00 & 215.00 & 12.65 \\
Soluble fraction & 215.00 & 105.00 & 48.84 \\
\hline
\end{tabular}

Table 2 \%yield of all pure compounds

\begin{tabular}{llll}
\hline Sample & $\begin{array}{l}\text { Weight of } \\
\text { soluble } \\
\text { fraction }(\mathbf{g})\end{array}$ & $\begin{array}{l}\text { Weight of pure } \\
\text { compounds } \\
\text { (mg) }\end{array}$ & \% Yield \\
\hline Pachypophyllin & 105.00 & 121.20 & 0.1152 \\
Galangin & 105.00 & 101.10 & 0.0963 \\
Chrysin & 105.00 & 21.20 & 0.0202 \\
4-Hydroxyacetophenone & 105.00 & 125.20 & 0.1192 \\
\hline
\end{tabular}

After purification, four pure compounds (Fig.1) were based on melting points and spectral analysis data as described below:

Pachypophyllin (1): colourless needles from recrystallization with ethyl acetate-hexane, $\mathrm{mp} 158-159.2{ }^{\circ} \mathrm{C}$; $[\alpha]^{25} 0$ (c. $0.8 ; \mathrm{CH}_{2} \mathrm{Cl}_{2}$ ), UV $\lambda_{\max } \ldots \mathrm{nm}(\operatorname{logs}): 227$ (3.24) and 289 (4.11); FTIR $v_{\max } \mathrm{cm}^{-1}: 2972,2926,2868,1711$, 1461, 1389, 1299, 1189, 1073, 1002, 982, and 924; ${ }^{1} \mathrm{H}$ NMR (400 MHz, CDCl3): $\delta 6.98$ (s, 2H, H-6/6'), 6.48 ( $\left.s, 2 \mathrm{H}, \mathrm{H}-3 / 3^{\prime}\right), 3.87$ ( $\left.m, 2 \mathrm{H}, \mathrm{H}-7 / 7^{\prime}\right), 3.86\left(s, 6 \mathrm{H}, 5 / 5^{\prime}-\right.$ $\left.\mathrm{OCH}_{3}\right), 3.85\left(s, 6 \mathrm{H}, 4 / 4^{\prime}-\mathrm{OCH}_{3}\right), 3.75\left(s, 6 \mathrm{H}, 2 / 2^{\prime}-\mathrm{OCH}_{3}\right)$, $2.31(d t, 5,1,2,1 \mathrm{~Hz}, 2 \mathrm{H}, \mathrm{H}-8 \alpha), 1.94(d t, 5,1,2,1 \mathrm{~Hz}, 2 \mathrm{H}$, $\mathrm{H}-8 \beta),{ }^{13} \mathrm{C}$ NMR (100 MHz, CDCl3): $\delta 151.0\left(\mathrm{C}-4 / 4^{\prime}\right)$, $147.5\left(\mathrm{C}-2 / 2^{\prime}\right), \quad 143.1 \quad\left(\mathrm{C}-5 / 5^{\prime}\right), 124.6 \quad\left(\mathrm{C}-1 / 1^{\prime}\right), 111.8$ (C-6/6'), $97.8\left(\mathrm{C}-3 / 3^{\prime}\right), 40.5\left(\mathrm{C}-7 / 7^{\prime}\right), 56.6\left(5 / 5^{\prime}-\mathrm{OCH} 3\right)$, 56.5 (2/2'-OCH3), 56.2 (5/5'-OCH3), 27.0 (C-8/8'). HR MS (ESI-TOF): $m / z$ found: $\left(\mathrm{m} / \mathrm{z} 411.1780[\mathrm{M}+\mathrm{Na}]^{+}\right.$, (calcd. for $\mathrm{C}_{22} \mathrm{H}_{28} \mathrm{O}_{6} \mathrm{Na}$, 411.1784).

Galangin (2): yellow powder from recrystallization with ethyl acetate-hexane, mp. $215-215{ }^{\circ} \mathrm{C}$; UV $\lambda_{\max \ldots} \mathrm{nm}(\operatorname{logs}): 267$ (3.44) and 370 (3.55); FTIR $v_{\max }$ $\mathrm{cm}^{-1}: 3607-3084,1659,1600,1550$ and $1260 ;{ }^{1} \mathrm{H}$ NMR $\left(400 \mathrm{MHz}, \mathrm{DMSO}-\mathrm{d}_{6}\right): \delta 12.36(1 \mathrm{H}$, br.s, $5-\mathrm{OH}), 8.14(2 \mathrm{H}$, $\left.m, \mathrm{H}-4^{\prime}\right), 7.53\left(3 \mathrm{H}, m, \mathrm{H}-3^{\prime}, 4^{\prime}, 5^{\prime}\right), 6.45\left(1 \mathrm{H}\right.$, br.s, $\left.\mathrm{H}-8^{\prime}\right)$, and $6.21\left(1 \mathrm{H}\right.$, br.s, $\left.\mathrm{H}-6^{\prime}\right),{ }^{13} \mathrm{C}-\mathrm{NMR}\left(100 \mathrm{MHz}\right.$, DMSO-d $\left.\mathrm{d}_{6}\right)$ ס: 176.4 (C-4), 164.3 (C-7), 160.8 (C-5), 155.9 (C-9), 145.5 (C-2), 137.0 (C-3), 130.8 (C-1'), 139.92 (C-4'), 128.6 (C-2', 6'), $127.6\left(\mathrm{C}-3^{\prime}, 5^{\prime}\right), 103.3$ (C-10), $98.4(\mathrm{C}-6)$, and 93.6 (C-8); HR MS (ESI-TOF): $m / z$ found $316.0331[\mathrm{M}+\mathrm{Na}]^{+}$, (calcd. for $\mathrm{C}_{15} \mathrm{H}_{10} \mathrm{O}_{5} \mathrm{Na}$, 316.0324).

Chrysin (3): yellow powder from recrystallization with $\mathrm{MeOH}$, m.p. $270.3-274.0{ }^{\circ} \mathrm{C}$; UV $\lambda_{\max \ldots} \mathrm{nm}$ (logs): 212 (4.66), 268 (4.56), 313 (4.17); FTIR $v_{\max } \mathrm{cm}^{-1}$ : 3434 (O-H stretching of phenol), 3012 (aromatic $\mathrm{C}-\mathrm{H}$ stretching), 
<smiles>COc1cc(OC)c(C2CCC2c2cc(OC)c(OC)cc2OC)cc1OC</smiles><smiles>O=c1c(O)c(-c2ccccc2)oc2cc(O)cc(O)c12</smiles><smiles>O=c1cc(-c2ccccc2)oc2cc(O)cc(O)c12</smiles><smiles>CC(=O)c1ccc(O)cc1</smiles>

3

4

Fig. 1 Phenolic compounds isolated from A. calamus were (1) pachypophyllin (2) galangin (3) chrysin and (4) 4-hydroxyacetophenone

1654 $(\mathrm{C}=\mathrm{O}$ stretching of ketone), $1612(\mathrm{C}=\mathrm{C}$ stretching), 1577 (aromatic $\mathrm{C}=\mathrm{C}$ stretching), $1169(\mathrm{C}-\mathrm{O}$ stretching of phenol), 1120, 1101, 1077, 1033, 999, 908, 842, 807, 782, 747, 733, 711, 693, 674, 642, 612, 572, 559, 511, 502, 461, 430, $405 \mathrm{~cm}^{-1} ;{ }^{1} \mathrm{H}\left(400 \mathrm{MHz}, \mathrm{DMSO}-\mathrm{d}_{6}\right) \delta 12.79(1 \mathrm{H}, s$, $\mathrm{OH}-5) 10.89(1 \mathrm{H}, s, \mathrm{OH}-7) 8.00\left(2 \mathrm{H}, d, \mathrm{~J}=8.0 \mathrm{~Hz}, \mathrm{H}-2^{\prime}\right.$, $\left.6^{\prime}\right) 7.51-7.56\left(3 \mathrm{H}, m, \mathrm{H}-3^{\prime}, 4^{\prime}, 5^{\prime}\right), 6.89(1 \mathrm{H}, s, \mathrm{H}-3), 6.47$ $(1 \mathrm{H}, s, \mathrm{H}-8), 6.18(1 \mathrm{H}, s, \mathrm{H}-6) ;{ }^{13} \mathrm{C}\left(100 \mathrm{MHz}, \mathrm{DMSO}-\mathrm{d}_{6}\right)$ $\delta 163.46(\mathrm{~s}, \mathrm{C}-2), 105.27$ (s,C-3), 182.27 (s,C-4), 157.82 (C-9), 161.96 (s, C-5), 99.35 (C- 6), 164.69 (C-7), 94.95 (C-8), 104.41 (C-10), 131.43 (s, C-1'), $126.23\left(\mathrm{C}-2^{\prime}, 6^{\prime}\right)$, $129.6\left(\mathrm{C}-3^{\prime}, 5^{\prime}\right)$; HR MS (ESI-TOF): $m / z$ found 277.0481 $[\mathrm{M}+\mathrm{Na}]^{+}$, (calcd. for $\mathrm{C}_{15} \mathrm{H}_{10} \mathrm{O}_{4} \mathrm{Na}, 277.0477$ ). 4-hydroxyacetophenone (4): white powder from recrystallization with $\mathrm{MeOH}$, m.p. $106.3-107.7^{\circ} \mathrm{C}$; UV $\lambda_{\max \ldots . . .} \mathrm{nm}(\operatorname{logs}): 219$ (4.09) and 275 (4.23); FTIR $v_{\max }$ $\mathrm{cm}^{-1}: 3310(\mathrm{O}-\mathrm{H}$ stretching of phenol), $1664(\mathrm{C}=\mathrm{O}$ stretching of ketone), 1604, 1578, 1512 (aromatic $\mathrm{C}=\mathrm{C}$ stretching), 1108 and 1074 (C-O stretching of phenol), 1022, 962, 849, 817, 668, 590, 568, 498, 489, $414 \mathrm{~cm}^{-1}$; ${ }^{1} \mathrm{H}\left(400 \mathrm{MHz}, \mathrm{CDCl}_{3}\right)(\delta \mathrm{ppm}) 7.91(2 \mathrm{H}, d, \mathrm{~J}=8.5 \mathrm{~Hz}$, $\mathrm{H}-2,6), 7.03(2 \mathrm{H}, d, \mathrm{~J}=8.5 \mathrm{~Hz}, \mathrm{H}-3,5), 2.56(s, 3 \mathrm{H}) \mathrm{ppm}$. ${ }^{13} \mathrm{C}$ NMR (100 MHz, CDCl $): 129.0$ (C-1), $132.0(\mathrm{C}-2,6)$, 115.5 (C-3,5), 198.4 (C-7), 161.3 (C-4), $26.3\left(\mathrm{CH}_{3}\right)$; HR MS (ESI-TOF): $m / z$ found $159.0426[\mathrm{M}+\mathrm{Na}]^{+}$, (calcd. for $\mathrm{C}_{8} \mathrm{H}_{8} \mathrm{O}_{2} \mathrm{Na}, 159.0422$ ).

Table $3 L_{50}$ values $(\mu \mathrm{g} / \mathrm{larvae})^{1}$ of the crude methanolic extract and isolated phenolic compounds from A. calamus against second instar S. litura larvae under laboratory conditions

\begin{tabular}{|c|c|c|c|c|c|c|}
\hline Extract & $\begin{array}{l}\text { Number of insects/ } \\
\text { dose }(n)\end{array}$ & $\mathrm{LD}_{50}{ }^{1}$ & UCL & $\mathrm{LCL}$ & Chi-square & $P$-level \\
\hline A. calamus crude methanolic extract & 150 & 7.438 & 7.507 & 7.369 & 3.21 & 0.043 \\
\hline Pachypophyllin & 150 & 6.512 & 6.623 & 6.398 & 1.56 & 0.031 \\
\hline Galangin & 150 & 4.718 & 4.717 & 4.729 & 1.29 & 0.063 \\
\hline Chrysin & 150 & 2.752 & 2.821 & 2.683 & 0.77 & 0.089 \\
\hline 4-Hydroxyacetophenone & 150 & 3.217 & 3.293 & 3.179 & 6.94 & 0.065 \\
\hline Control $^{2}$ & 150 & - & - & - & - & - \\
\hline
\end{tabular}

\footnotetext{
${ }^{1} \mathrm{LD}_{50}$ represents the median lethal dose
}

${ }^{2}$ Control is treatment with acetone only 


\section{Toxicity results}

The toxicity in terms of the median lethal dose $\left(\mathrm{LD}_{50}\right)$ values of $A$. calamus methanolic crude extract, pachypophyllin, galangin, chrysin and 4-hydroxyacetophenone were $7.438,6.512,4.718,2.752$ and $3.217 \mu \mathrm{g} /$ larva, respectively (Table 3 ). There are no mortality occurs in control treatment. From our results, the A. calamus methanolic extract showed toxicity on second instar $S$. litura larvae under laboratory conditions, and chrysin could be an active ingredient, as it showed the highest toxicity (Table $1, \mathrm{LD} 50=2.752 \mu \mathrm{g} /$ larva). No mortality occurred in the control group. Although other isolated phenolic compounds, such as pachypophyllin, galangin and 4-hydroxyacetophenone, showed lower relative toxicities, they still all showed toxicity to the larvae. In addition, the toxicity to $S$. litura second instar larvae was dose-dependent.

\section{Detoxification enzyme activities}

Detoxification enzyme analysis was carried out with the methanolic crude extract and all isolated phenolic compounds to determine the detoxification ability of the treated larvae. Our results showed that CE activity was reduced after treatment with all the isolated extracts (Table 4) compared with that of the control (the treatment in which larvae were not exposed to any plant compounds), except for after treatment with the crude methanolic extract of $A$. calamus. Galangin showed the highest reduction in activity, with an approximately 1.4fold reduction. GST activity was significantly induced after all treatments compared to that of the control group (Table 4). The crude methanolic extract showed the highest induction (1.65- times). Among the phenolic compounds, galangin showed the highest induction (1.5 times) (Table 4).

\section{Discussion}

This is the first study that showed that crude A. calamus methanolic extract had an $\mathrm{LD}_{50}$ value of $7.438 \pm 69.8 \mu \mathrm{g} /$ larva against secondary instars of $S$. litura. The toxicity of the bioeffective A. calamus methanolic extract on $S$. litura was also confirmed (Table 3).

Yooboon et al. [15] reported that this plant's crude ethanolic extract exhibited contact toxicity and antifeedant activity against second instar S. litura. Moreover, the highest concentration of $A$. calamus caused an approximately $90 \%$ mortality of Callosobruchus analis at $13.2625 \mu \mathrm{g} / \mathrm{cm}^{2}$ [39]. Several reports have published that $A$. calamus showed some insecticidal efficiency; for example, the leaf-dipping toxicity of $A$. calamus ethanolic extracts caused mortality against third instar larvae of P. xylostella [40].

Melani et al. [41] showed that $A$. calamus essential oil caused the highest toxicity on $S$. litura larvae $\left(\mathrm{LD}_{50}\right.$ values $\sim 5.86 \mu \mathrm{g} /$ larvae). Compared with other plants using the same solvent extract, the A. galangal methanolic extract showed toxicity and growth inhibition against $S$. litura larvae [42].

According to Imam and Tajuddeen [43], A. calamus phytochemical studies have reported glycosides, saponins, flavonoids, tannins, mucilage, polyphenolic compounds, and some volatile oils in this plant. There have been some reports that have shown that beta-asarone is a compound contained within A. calamus that demonstrated insecticidal efficiency against the controls of Prostephanus truncates (Horn) [44] and S. litura [45]. Several reported flavonoid compounds were also found in the $A$. calamus extract, such as uvangoletin, galangin, chrysin (5,7-dihydroxy flavone), 5-hydroxy-4, 7-dimethoxy-flavone and pinostrobin [46]. Moreover, there have been a few reports on the efficiency of other flavonoid compounds against $S$. litura. In addition, this

Table 4 Detoxification enzyme activities ${ }^{1}$ of second instar S. litura larvae after treatment with the crude extract and the isolated phenolic compounds from A. calamus at the median lethal dose

\begin{tabular}{lllll}
\hline & Carboxylesterase $^{c}$ & Effect & Glutathione-S-transferase $^{\mathbf{3}}$ & Effect \\
\hline Control $^{4}$ & $776.60 \pm 25.40 \mathrm{a}$ & - & $4.98 \pm 0.001 \mathrm{e}$ & - \\
A. calamus crude extract & $780.97 \pm 31.51 \mathrm{a}$ & No effect & $8.20 \pm 0.003 \mathrm{a}$ & Induction \\
Pachypophyllin & $739.63 \pm 66.32 \mathrm{~b}$ & Reduction & $6.06 \pm 0.002 \mathrm{~d}$ & Induction \\
Galangin & $553.21 \pm 15.80 \mathrm{~d}$ & Reduction & $7.46 \pm 0.005 \mathrm{~b}$ & Induction \\
Chrysin & $631.85 \pm 19.42 \mathrm{c}$ & Reduction & $6.30 \pm 0.001 \mathrm{C}$ & Induction \\
4-Hydroxyacetophenone & $657.85 \pm 94.16 \mathrm{c}$ & Reduction & $7.06 \pm 0.002 \mathrm{~d}$ & Induction
\end{tabular}

${ }^{1}$ In all experiments, the mean values followed by the same letter within the same column are not significantly different using Tukey's HSD test ( $\left.P>0.05\right)$. In each experiment, 30 larvae/treatment in five replicates were used ( $n=150$ per treatment)

${ }^{2}$ Carboxylesterase activity $\pm \mathrm{SE}$ (nM p-nitrophenol/min/mg protein)

${ }^{3}$ Glutathione-S-transferase activity $\pm \mathrm{SE}\left(\times 10^{-3} \mathrm{CDNB}\right.$ conjugated product $/ \mathrm{mg}$ protein $/ \mathrm{min}$ )

${ }^{4}$ Control is treatment with acetone only 
research found three flavonoid compounds (galangin, chrysin, and pachypophyllin) that showed toxicity to S. litura larvae, with $\mathrm{LD}_{50}$ values of $6.512 \pm 114.2 \mu \mathrm{g} /$ larva, $4.718 \pm 114 \mu \mathrm{g} / \mathrm{larva}$, and $2.752 \pm 69.2 \mu \mathrm{g} /$ larva for pachypophyllin, galangin, and chrysin, respectively (Table 1). Chrysin seemed to be an active ingredient (Table 3).

Chrysin is a phenolic compound in several plants. In a previous report, chrysin contributed to antioxidant activity as an immune enhancer in fish [47]. Avila et al. [48] calculated an $\mathrm{LC}_{50}$ of $28.79 \mathrm{ppm}$ for this compound against S. frugiperda. Chrysin also had antifeedant activity on S. litura larvae [49].

Herbivorous animals normally use detoxification enzymes to metabolize xenobiotic compounds [50]. The mechanism of $S$. litura resistance towards insecticides must be understood to increase control efficiency by studying the functions of the detoxification enzyme activities in S. litura. Several reports found that resistance in S. litura was dependent on certain detoxification enzyme activities, such as GST, CE, and cytochrome P450. The enzyme activities of CE and GST were observed to be higher in Spodoptera spp. that are resistant to pesticides $[51,52]$.

Our results showed that CE had significantly reduced activities in larvae that survived for $24 \mathrm{~h}$ after exposure to all isolated phenolic compounds from A. calamus compared to the control group and the $A$. calamus crude extract group.

Generally, at the biochemical level, CE plays a role in the tolerance to allelochemical intake [53]. Our results showed that $\mathrm{CE}$ reduction affected some specific functions in insects, such as the neurotransmitter acetylcholine or juvenile hormones $[54,55]$. Pesticides that induced these enzymes always showed resistance mechanisms $[53,56]$.

However, as seen in Table 4, GST activity was significantly induced; they were catalysed enzymes that detoxified the endogenous compounds involved in Spodoptera spp. resistance mechanisms [57]. Lepidoptera always showed an increase in GST activity during pesticide resistance [58]. Our results indicate that GST could be an important detoxification enzyme of $S$. litura to fight against the activity of the $A$. calamus extract. However, this process must be evaluated in further studies.

\section{Conclusions}

The crude methanolic extract of A. calamus and its isolated compound, chrysin, can cause toxicity to $S$. litura larvae (Table $1, \mathrm{LD}_{50}=2.752 \mu \mathrm{g} / \mathrm{larva}$ ). There was a significant reduction in detoxification enzymes as CE activity among the isolated compounds (Table 4). Chrysin could be a main active ingredient to control S. litura and may be used as an alternative to minimize the application of chemical insecticides.

\begin{abstract}
Abbreviations
$\mathrm{LD}_{50}$ : Median lethal dose; L:D: Light:dark; CE: Carboxylesterase; GST:

Glutathione-S-transferase; pNPA: $p$-Nitrophenylacetate; CDNB: 1-Chloro-2,4-dinitrobenzene; $\mathrm{MeOH}$ : Methanol $(\mathrm{MeOH})$.
\end{abstract}

\section{Acknowledgements}

We would like to thank the supported grant from the Graduate School, Kasetsart University, ISB funding for the Faculty of Science, Kasetsart University, the research funding of the Department of Zoology, Faculty of Science, Kasetsart University.

\section{Authors' contributions}

VB and SN designed the experiment. PW, VB and TY performed the experiments. VB, SN, PW and NK wrote and reviewed the paper. All author checked all the details, read and approved the final manuscript.

\section{Funding}

This research was funded by Graduate School, Kasetsart University, ISB funding from the Faculty of Science, Kasetsart University, the research funding of the Department of Zoology, Faculty of Science, Kasetsart University.

Availability of data and materials

All data are presented in Tables 1, 2, 3, 4 and Fig. 1.

\section{Declarations}

Ethics approval and consent to participate

All experimental procedures in this research were performed with the approval of an appropriate animal Ethics Committee of Kasetsart University, Thailand.

\section{Consent for publication}

This research has been confirmed for publication in the journal.

\section{Competing interests}

The authors have no conflicts of interest.

\section{Author details}

${ }^{1}$ Animal Toxicology and Physiology Speciality Research Unit, Department of Zoology, Faculty of Science, Kasetsart University, Phahonyothin Road, Bangkok 10900, Thailand. ${ }^{2}$ Biology Department, Faculty of Science and Technology, Rajamangala University of Technology Thanyaburi, Pathumthani 12110, Thailand. ${ }^{3}$ Nakhonsawan Campus, Mahidol University, 402/1 Moo 5 Khaothong, Phrayuhakiri District, Nakhonsawan 60130, Thailand.

Received: 14 August 2021 Accepted: 15 November 2021

Published online: 15 January 2022

\section{References}

1. Kaleeswaran G, Firake DM, Sanjukta R, Behere GT, Ngachan SV. Bambooleaf prickly ash extract: a potential bio-pesticide against oriental leaf worm, Spodoptera litura (Fabricius)(Lepidoptera: Noctuidae). J Environ Manage. 2018;208:46-55. https://doi.org/10.1016/j.jenvman.2017.12.017.

2. Pogue GM. A world revision of the genus Spodoptera Guenée (Lepidoptera: Noctuidae). Memb Entomol Soc Am. 2002;43:1-202.

3. de Freitas Bueno RC, de Freitas BA, Moscardi F, Postali Parra JR, HoffmannCampo CB. Lepidopteran larva consumption of soybean foliage: basis for developing multiple-species economic thresholds for pest management decisions. Pest Manag Sci. 2011;67(2):170-4. https://doi.org/10.1002/ps. 2047

4. Abbas N, Shad SA, Razaq M. Fitness cost, cross resistance and realized heritability of resistance to imidacloprid in Spodoptera litura (Lepidoptera: Noctuidae). Pest Biochem Phys. 2012;103:181-8. https://doi.org/10. 1016/j.pestbp.2012.05.001.

5. Abbas N, Samiullah SSA, Razaq M, Waheed A, Aslam M. Resistance of Spodoptera litura (Lepidoptera: Noctuidae) to profenofos: relative fitness 
and cross resistance. Crop Prot. 2014;58:49-54. https://doi.org/10.1016/j. cropro.2014.01.002.

6. Huang Q, Wang X, Yao X, Gong C, Shen L. Effects of bistrifluron resistance on the biological traits of Spodoptera litura (Fab.) (Noctuidae: Lepidoptera). Ecotoxicology. 2019;28:323-32. https://doi.org/10.1007/ s10646-019-02024-2.

7. Ruttanaphan T, Pluempanupat W, Bullangpoti V. Cypermethrin resistance in Spodoptera litura (Fabricius)(Lepidoptera:Noctuidae) from three locations in Thailand and detoxification enzyme activities. Agric Nat Resour. 2018;52:484. https://doi.org/10.1016/j.anres.2018.10.014.

8. Firake DM, Thubru DP, Behere GT. Eco-toxicological risk and impact of pesticides on important parasitoids of cabbage butterflies in cruciferous ecosystem. Chemosphere. 2017;168:372-83. https://doi.org/10.1016/j. chemosphere.2016.10.071.

9. Koul O. The handbook of naturally occurring insecticidal toxins. Wallingford: Academic; 2016. p. 864

10. Schmutterer H. Properties and potential of natural pesticides from the neem tree Azadirachta indica. Annu Rev Entomol. 1990;35:271-97. https://doi.org/10.1146/annurev.en.35.010190.001415.

11. Koul O, Wahab S. Neem: today and in the new millennium. 1st ed. Springer; 2004.

12. Ling $\mathrm{SQ}$, He B, Zeng DQ, Tang WW. Effects of botanical pesticide itol A against the tobacco cutworm, Spodoptera litura (Fab.). Environ Sci Pollut Res. 2020;27:12181-91. https://doi.org/10.1007/s11356-020-07824-2.

13. Ratwatthananon A, Yooboon T, Bullangpoti V, Pluempanupat W. Insecticidal activity of Piper retrofractum fruit extracts and isolated compounds against Spodoptera litura. Agric Nat Resour. 2020;54:447-52.

14. Bhuiyan KR, Hassan E, Isman MB. Growth inhibitory and lethal effects of some botanical insecticides and potential synergy by dillapiol in Spodoptera litura (Fab.) (Lepidoptera: Noctuidae). J Plant Dis Prot. 2001;82-8.

15. Yooboon T, Pengsook A, Ratwatthananon A, Pluempanupat W, Bullangpoti V. A plant-based extract mixture for controlling Spodoptera litura (Lepidoptera: Noctuidae). Chem Biol Technol Agri. 2019;6:1-10. https:// doi.org/10.1186/s40538-019-0143-6.

16. Pengsook A, Puangsomchit A, Yooboon T, Bullangpoti V, Pluempanupat W. Insecticidal activity of isolated phenylpropanoids from Alpinia galanga rhizomes against Spodoptera litura. Nat Prod Res. 2020. https://doi.org/10. 1080/14786419.2020.1747461

17. Shukla R, Kumar A, Prasad CS, Srivastava B, Dubey NK. Efficacy of Acorus calamus L. leaves and rhizome on mortality and reproduction of Callosobruchus chinensis L. (Coleoptera: Bruchidae). Appl Entomol Zool. 2009:44:241-7. https://doi.org/10.1303/aez.2009.241.

18. Esfandiari E, Ghanadian M, Rashidi B, Mokhtarian A, Vatankhah AM. The effects of Acorus calamus $L$. in preventing memory loss, anxiety, and oxidative stress on lipopolysaccharide-induced neuroinflammation rat models. J Prev Med. 2018;9:85. https://doi.org/10.4103/ijpvm.IJPVM_75_18.

19. Senthilkumar A, Venkatesalu V. Larvicidal potential of Acorus calamus L. essential oil against filarial vector mosquito Culex quinquefasciatus (Diptera: Culicidae). Asian Pac JTrop Dis. 2012;2:324-6. https://doi.org/10. 1016/S2222-1808(12)60070-X.

20. Koul O, Smirle MJ, Isman MB. Asarones from Acorus calamus L. oil. J Chem Ecol. 1990;16:1911-20. https://doi.org/10.1007/BF01020504.

21. Risha EM, El-Nahal AK, Schmidt GH. Toxicity of vapours of Acorus calamus L. oil to the immature stages of some stored-product Coleoptera. J Stored Prod Res. 1990;26:133-7. https://doi.org/10.1016/0022-474X(90)90013-I.

22. Bruwer EE, Van Der Bank FH, Steyn GJ, Wink M. Phylogenetic relationships between Synodontis species: some preliminary results. Afr J Aquat Sci. 2000;25:89-92. https://doi.org/10.2989/160859100780177785.

23. Bahukhandi A, Rawat S, Jugran AK, Bhatt ID, Rawal RS. Seasonal variation in phenolics and antioxidant activity of Acorus calamus Linn.: an important medicinal plant of Himalaya. Natl Acad Sci Lett. 2020;44:13-5.

24. Dinev T, Tzanova M, Velichkova K, Dermendzhieva D, Beev G. Antifungal and antioxidant potential of methanolic extracts from Acorus calamus L. Chlorella vulgaris Beijerinck, Lemna minuta Kunth and Scenedesmus dimorphus (Turpin) Kützing. Appl Sci. 2021;11:4745. https://doi.org/10. 3390/app11114745.

25. Muthulakshmi T, Saleh AM, Kumari NV, Palanichamy V. Screening of phytochemicals and in vitro antioxidant activity of Acorus Calamus. Int J Drug Dev \& Res. 2015;7:0975-9344.
26. Kafle L, Shih CJ. Insecticidal activities of compounds from sweet flag (Acorus Calamus) against red imported fire ants Solenopsis invicta (Hymenoptera: Formicidae). Sociobiology. 2017:64:398-403.

27. Adfa M, Livandri F, Meita NP, Manaf S, Ninomiya M, Gustian I, Putranto AM, Supriati R, Koketsu M. Termiticidal activity of Acorus calamus Linn. rhizomes and its main constituents against Coptotermes curvignathus Holmgren. J Asia Pac Entomol. 2015;18:47-50. https://doi.org/10.1016/j. aspen.2014.10.012.

28. Alves AP, Corrêa AD, Alves DS, Saczk AA, Lino JB, Carvalho GA. Toxicity of the phenolic extract from jabuticabeira (Myrciaria cauliffora (Mart.) O. Berg) fruit skins on Spodoptera frugiperda. Chil J Agric Res. 2014;74:200-4. https://doi.org/10.4067/S0718-58392014000200011.

29. Appel HM, Schultz JC. Activity of phenolics in insects: the role of oxidation. In: Hemingway RW, Laks PE, editors. In plant polyphenols. Boston: Academic; 1992. p. 609-20. https://doi.org/10.1007/978-1-4615-3476-1_34.

30. Yooboon T, Pengsook A, Poonsri W, Pluempanupat W, Bullangpoti V. Toxicity of Phenylpropanoids from Alpinia galanga (Zingiberaceae) extracts against Spodoptera exiqua Hübner (Lepidoptera: Noctuidae). Phytoparasitica. 2020;48:833-40. https://doi.org/10.1007/s12600-020-00830-7.

31. Nobsathian S, Saiyaitong C, Koul O, Pluempanupat W, Bullangpoti V Kumrungsee N. The insecticidal of Piper ribesioides (Piperales: Piperaceae) extracts and isolated allelochemicals and their impact on the detoxification enzymes of Spodoptera exigua (Lepidoptera: Noctuidae). Phytoparasitica. 2021;49:659-73. https://doi.org/10.1007/s12600-021-00891-2.

32. Ngadjui BT, Lontsi D, Ayafor JF, Sondengam BL. Pachypophyllin and Pachypostaudins A and B: three bisnorlignans from Pachypodanthium staudtii. Phytochemistry. 1989;28:231-4. https://doi.org/10.1016/00319422(89)85044-7.

33. Zhang X, Cheng S, Li H, Zhang X, Chen F, Li Y, Zhang J, Tan Y. Isolation and identification of two galangin metabolites from rat urine and determination of their in vitro hypolipidemic activity. Trop J Pharm Res. 2016;15:1235-41. https://doi.org/10.4314/tjpr.v15i6.16.

34. Deka DC, Kumar V, Prasad C, Srivastava RB. Isolation of flavonoids from Oroxylum indicum (Vent.) stem bark and their antioxidant activity using DPPH assay. Inter J Chem Pharm Sci. 2014;2:783-7.

35. Youn UJ, Lee YJ, Jeon HR, Shin HJ, Son YM, Nam JW, Han AR, Seo EK. A pyridyl alkaloid and benzoic acid derivatives from the rhizomes of Anemarrhena asphodeloides. Nat Prod Sci. 2010;16:203-6.

36. Bullangpoti V, Wajnberg E, Audant P, Feyereisen R. Antifeedant activity of Jatropha gossypifolia and Melia azedarach senescent leaf extracts on Spodoptera frugiperda (Lepidoptera: Noctuidae) and their potential use as synergists. Pest Manag Sci. 2012;68:1255-64. https://doi.org/10.1002/ps. 3291.

37. Oppenoorth FJ, Van der Pas LJ, Houx NW. Glutathione-S-transferases and hydrolytic activity in a tetrachlorvinphos-resistant strain of housefly and their influence on resistance. Pestic Biochem Phys. 1979;11:176-88. https://doi.org/10.1016/0048-3575(79)90057-9.

38. Bradford MM. A rapid sensitive method for quantification of microgram quantities of protein utilising the principle of protein-Dye Binding. Anal Biochem. 1976;72:248-54. https://doi.org/10.1016/0003-2697(76) 90527-3.

39. Gul N, Khan MF, Nafees MA. Toxicity and effects of Nimolcine (Neem compound) and Acorus calamus on cholinesterase enzyme of Callosobrunchus analis in comparison with chemical pesticide. J Chem Soc Pak. 2019:41:383-7. http://link.gale.com/apps/doc/A584333134/AONE?u= anon $\sim 47645 \mathrm{c} 0 \&$ sid $=$ googleScholar\&xid $=4$ bb35721. Accessed 16 Oct 2021.

40. Jiyavorranant T, Chanbang Y, Supyen D, Sonthichai S, Jatisatienr A. The effects of Acorus calamus Linn. and Stemona Tuberose Lour. extracts on the insect pest, Plutella xylostella (Linnaeus). International Conference on Medicinal and Aromatic Plants (Part II). 2001. https://www.actahort.org/ books/597/597 32.htm. Accessed 17 Oct 2021.

41. Melani D, Himawan T, Afandhi A. Bioactivity of sweet flag (Acorus calamus Linnaeus) essential oils against Spodoptera litura Fabricius (Lepidoptera: Noctuidae). J Trop Life Sci. 2016;6:86-90. https://doi.org/10.11594/jtls.06.02. 04

42. Datta R, Kaur A, Saraf I, Singh IP, Kaur S. Effect of crude extracts and purified compounds of Alpinia galanga on nutritional physiology of a polyphagous lepidopteran pest, Spodoptera litura (Fabricius). Ecotoxicol Environ Saf. 2019;168:324-9. https://doi.org/10.1016/j.ecoenv.2018.10. 065. 
43. Imam TS, Tajuddeen UM. Qualitative phytochemical screening and larvicidal potencies of ethanolic extracts of five selected macrophyte species against Anopheles mosquitoes (diptera: culicidae). Res J Environ Toxicol. 2013;2:121-5.

44. Schmidt GH, Streloke M. Effect of Acorus calamus (L.) (araceae) oil and its main compound beta- asarone on Prostephanus truncatus (horn.) (Coleoptera, Bostrichidae). J Stored Prod Res. 1994;30:227-35. https://doi. org/10.1016/0022-47X(94)90050-R.

45. Yooboon T, Bullangpoti $\mathrm{V}$, Kainoh Y. Contact toxicity and antifeedant activity of binary mixtures of piperine and $\beta$-asarone against the crop pests, Spodoptera litura and Mythimna separata (Lepidoptera: Noctuidae). Int J Pest Manag. 2021. https://doi.org/10.1080/09670874.2020.1853275.

46. Reddy S, Rao G, Shetty B, Hn G. Effects of Acorus calamus Rhizome extracts on the Neuromodulatory system in restraint stress male rats. Turk Neusosurg. 2015;25:425-31. https://doi.org/10.5137/1019-5149.jtn. 11405-14.1.

47. Cerit O, Koc F. The effects of chrysin on cypermethrin-induced acute intoxication in rainbow trout (Oncorhynchus mykiss). Fish Aquatic Life. 2019;27:102-11. https://doi.org/10.2478/aopf-2019-0011.

48. Murillo MC, Suarez LE, Salamanca JA. Insecticidal activity on Spodoptera frugiperda (Lepidoptera: Noctuidae) of the compounds isolated from aerial part of Piper septuplinervium (Miq.) C. DC. and the inflorescences of Piper subtomentosum Trel. \&Yunck. (Piperaceae). Quim Nova. 2014;37:442-6. https://doi.org/10.5935/0100-4042.20140067.

49. Morimoto M, Tanimoto K, Nakano S, Ozaki T, Nakano A, Komai K. Insect antifeedant activity of flavones and chromones against Spodoptera litura. J Agric Food Chem. 2003;51:389-93. https://doi.org/10.1021/jf025627a.

50. Ramsey JS, Ridert DS, Walsht TK, De Vos M, Gordons KHJ, Ponnala L, Macmil SL, Roe BA, Jander G. Comparative analysis of detoxification enzyme in Acyrthosiphon pisum and Myzus persicae. Insect Mol Biol. 2010;19:15564. https://doi.org/10.1111/j.1365-2583.2009.00973.x.

51. Yu SJ. Induction of detoxification enzymes by triazine herbicides in the fall armyworm, Spodoptera frugiperda (J.E. Smith). Pestic Biochem Phys. 2004;80:113-22. https://doi.org/10.1016/j.pestbp.2004.06.005.
52. Ruttanaphan T, Pluempanupat W, Bullangpoti V. Cypermethrin resistance in Spodoptera litura (Fabricius) (Lepidoptera: Noctuidae) from three locations in Thailand and detoxification enzyme activities. Agric Nat Resour. 2008;52:484-8. https://doi.org/10.1016/j.anres.2018.10.014.

53. Li X, Schuler MA, Berenbaum MR. Molecular mechanisms of metabolic resistance to synthetic and natural xenobiotics. Annu Rev Entomol. 2007;52:231-53. https://doi.org/10.1016/j.anres.2018.10.014.

54. Taylor P, Radic Z. The cholinesterase: from gene to proteins. Annu Rev Pharmacol Toxicol. 1994;34:281-320.

55. Riddiford ML, Hiruma K, Zhou X, Nelson CA. Insights into the molecular basis of the hormonal control of molting and metamorphosis from Manduca sexta and Drosophila melanogaster. Insect Biochem Mol Biol. 2003;33:1327-38. https://doi.org/10.1016/j.ibmb.2003.06.001.

56. Simon JY, Hsu EL. Induction of detoxification enzymes in phytophagous insects: role of insecticide synergists, larval age, and species. Insect Biochem Physiol. 1993. https://doi.org/10.1002/arch.940240103.

57. Deng H, Huang Y, Feng Q, Zheng S. Two epsilon glutathione S-transferase cDNAs from the common cutworm, Spodoptera litura: characterization and developmental and induced expression by insecticides. J Insect Physiol. 2009;55:1174-83. https://doi.org/10.1016/j.jinsphys.2009.08.017.

58. Ortelli F, Rossiter L, Vontas J, Ranson H, Hemingway J. Heterologous expression of four glutathione transferase genes genetically linked to a major insecticide-resistance locus from the malaria vector Anopheles gambiae. Biochem J. 2003;373:957-63. https://doi.org/10.1042/bj200 30169.

\section{Publisher's Note}

Springer Nature remains neutral with regard to jurisdictional claims in published maps and institutional affiliations.

\section{Submit your manuscript to a SpringerOpen ${ }^{\circ}$ journal and benefit from:}

- Convenient online submission

- Rigorous peer review

- Open access: articles freely available online

- High visibility within the field

Retaining the copyright to your article

Submit your next manuscript at springeropen.com 